\title{
A talajtulajdonságok térbeli változatossága és a növényzet közötti összefüggés a kiskunsági Péteri-tó melletti szikes területen
}

\author{
${ }^{1}$ MILE ORSOLYA, ${ }^{1}$ MÉSZÁROS ILONA, ${ }^{1}$ VERES SZILVIA és \\ ${ }^{2}$ LAKATOS GYULA \\ ${ }^{1}$ Debreceni Egyetem, Növénytani Tanszék \\ ${ }^{2}$ Debreceni Egyetem, Alkalmazott Ökológiai Tanszék
}

A Pannon-medencében természetes folyamatok eredményeként egykori ártereken, a Tisza- és a Duna-síkon, valamint a homok- és löszhátságok lefolyástalan medencéiben alakultak ki szikes területek. A szikes talajok aránya az összterülethez képest európai viszonylatban Magyarországon a legnagyobb (SZABOLCS \& MOLNÁR, 1980). Hazai szikeseink jelentős része a Duna-Tisza közén helyezkedik el (SZABOLCS \& JASSÓ, 1959, 1961). A Péteri-tó tagja a Duna-Tisza közén a homokhát vízválasztótól keletre található, számos ÉNyDK-i irányú vonulatban elterülő szikes tavak láncolatának (UNGÁR, 1956).

A Duna-Tisza közi szikes területek jelentős része védett, illetve fokozottan védett. Védetté nyilvánításuk elsősorban az eredeti vegetáció- és élőhelytípusok megőrzése érdekében történt. Ezen területek természetes állapotának megőrzése, valamint a természetvédelmi szempontú kezelési tervek kialakítása érdekében folyó kutatások elsősorban a vegetáció tér- és időbeni mintázatának, illetve az azt meghatározó és befolyásoló tényezőknek a megismerésére irányulnak (RAJKAI et al., 1990).

Vegetációdinamikai tárgyú kutatások esetében fontos a növényzeti típust meghatározó ökológiai tényezők helyes kiválasztása és vizsgálata (BARNA, 1982). Szikes területek ökológiai jellemzése során a természetes vegetáció vizsgálata mellett elengedhetetlen a talaj analízise. Ezek rendszerint csak egymást kiegészítve nyújtanak megfelelő információt a térbeni és időbeni változásokról (TÓTH et al., 1998). Az általában változatos mikrodomborzati feltételekkel rendelkező, a víz- és talajviszonyok szempontjából rendkívül eltérő tulajdonságú zónákkal jellemezhető szikes területek kitűnő lehetőséget kínálnak ilyen jellegü kutatásokhoz.

Szikes területek vizsgálata során a florisztikai, növényföldrajzi munkák mellett (MÁTHÉ, 1933; PRODAN, 1915; SoÓ, 1934; TUZSON, 1915) már egészen korai tanulmányokban megjelent a növényzet térbeni elrendeződésében mutat-

* A Magyar Talajtani Társaság és a Magyarhoni Földtani Társulat Mérnökgeológiai Szakosztálya 2000. február 9-én, a szikesedés témakörében rendezett előadóülésén elhangzott előadás anyaga 
kozó törvényszerüségek feltárásának igénye. Szikes területek mikrodomborzati, mikromorfológiai leírásával (STRÖMPL, 1931) párhuzamosan megtörtént a mikrodomborzathoz illeszkedő növényzeti zónák leírása (RAPAICS, 1927), valamint az előforduló növénytársulások és termőhelyi viszonyaik jellemzése (MAGYAR, 1928). BODROGKÖZY 1960-as években készült szikes tanulmánysorozatában (BODROGKÖZY, 1962, 1965a,b,c, 1966, 1970a,b) már nagyszámú talajvizsgálati eredménnyel támasztja alá a szikes zonációsor növénytársulásainak és bizonyos talajtulajdonságokkal jellemezhető élőhelyeik közötti összefüggéseket, továbbá megadja számos szikes terület növénytársulás-sorozatának leírását.

A szikes területek növényzetének térbeni elrendeződését, a növényzet aktuális állapotának rögzítését célzó munkák egy része különböző távérzékelési módszerek, elsősorban légi fotók alapján készített vegetáció térképekre támaszkodik (BAGI, 1986, 1988, 1990). A légi fotók alkalmazhatóságának feltétele a jelentős mennyiségü terepi referenciaadat felhasználása a légi felvételen szubjektíve elhatárolt foltok beazonosításához (RAJKAI et al., 1990). Egy terület növényzete és a talajviszonyok közötti összefüggések vizsgálata során azonban egyre inkább felmerül az igény a légi felvételek hordozta információk kvantitatív kezelésére, illetve a fényképről történő mintavételezésre (RAJKAI et al., 1990; KERTÉSZ \& TÓTH, 1994).

A talajtulajdonságok térbeni változása és a növényzet közötti összefüggések vizsgálata során felmerülő kérdések közül a mintavételi pontok helyének és sürüségének megválasztása nagy jelentőséggel bír (KERTÉSZ \& TÓTH, 1994; TÓTH \& KERTÉSZ, 1993; TÓTH \& RAJKAI, 1994). A mintavételi pontok szükséges sürüsége nagymértékben függ a vizsgálandó terület mozaikosságának, azaz a légi fotó foltosságának mértékétől (KERTÉSZ \& TÓTH, 1994; TÓTH \& KERTÉSZ, 1993). Mivel a növényzet összetétele adott körülmények között egyértelmü indikátora a talajtulajdonságoknak (MAGYAR, 1928; BODROGKÖZY, 1965; TÓTH et al., 1991, 1998; TÓTH \& RAJKAI, 1994; RAJKAI et al., 1998), és bizonyos növényfajok előfordulása kvantitative tájékoztathat a talajtulajdonságokról (TÓTH \& RAJKAI, 1994), a növényzet összetételének változása alapján a mintavételi pontok szükséges sürüsége előre becsülhető.

A légi felvételen kijelölt és a terepen pontosan beazonosított helyzetü területek növénymintázatának és az ugyanott végzett talajmintavételezésböl származó adatok sokváltozós statisztikai kiértékelése és egymással történő összevetése módot adhat arra, hogy a légi fotón szubjektíve kijelölt kontúrok és a pontos terepvizsgálatok adatait összevethessük, ezáltal a vegetáció térkép reprezentativitását növeljük.

A Péteri-tói Természetvédelmi Területen végzett vizsgálataink elsősorban a növényzet zonációsorának és a mikrodomborzati viszonyok változásaival összefüggően alakuló talajjellemzők közötti kapcsolat minél sokoldalúbb feltárására és a területröl - légi fotó alapján, terepi referenciaadatok felhasználásával - készült vegetáció térkép reprezentativitásának a tesztelésére irányultak. 


\section{Anyag és módszer}

A vizsgálati terület. - A Péteri-tó a Kecskemét-Kiskunfélegyháza irányban húzódó löszterület DNy-i részén helyezkedik el (VÁRALLYAY et. al., 1984), tagja a Kiskunságon végighúzódó szikes tóláncolatnak. A tó és környéke természetvédelmi kezelés alatt áll, 1976-tól a Kiskunsági Nemzeti Park területéhez tartozik. A vizsgálati területet a jelenleg halastóként müködtetett, szabályozott vízállású tó partjától $500 \mathrm{~m}$-re, DNy-i irányban jelöltük ki. A tájegységre jellemző uralkodó ÉNy-DK-i szélirány a mikrodomborzat alakulásában meghatározó, melyet a kutatási területen a vízállásos részből 1-1,5 m-re kiemelkedő hátak ÉNy-DK irányultsága bizonyít. A hátak ÉK-i oldala fokozatosan ellaposodó, a DNy-i oldalak meredekebbek. A változatos mikrodomborzatú felszín mélyebb részei gyakran késő nyárig vízborítottak. A vízállásos részekböl a homokhátak szigetszerüen emelkednek ki.

Terepi vizsgálatok. - Az egyes növényzeti egységek kiterjedésének és elhelyezkedésének áttekinthetősége céljából a részletes terepfelmérés és a különböző növénytársulások azonosítása alapján elkészült a vizsgált terület 1:5000 méretarányú vegetáció térképe (1. ábra). A vegetáció térkép elkészítéséhez az Állami Erdészeti Hivatal 1991-es, 91-031-es repülési számú légi fotója alapján készített 1:2500 méretarányú nagyítását használtuk fel.

A mikrodomborzat és a növényzet térbeli elrendeződése közötti összefüggés vizsgálata során 1999 júniusában növényzeti felvételezést készítettünk $30 \mathrm{~m}$ hosszú transzekt mentén. A transzekt a térképezett terület K-i részén fekvő homokhát tetejéröl indul és DK-i irányban fut le a hátoldalon a mélyebb, vízborította részekig (1. ábra). A növényzet felvételezése a transzekt mentén $1 \mathrm{~m}^{2}$ nagyságú kvadrátokban történt. Az egyes kvadrátokban megállapítottuk az elöforduló növényfajok számát és \%-os relatív borítását.

A talajmintavétel a növényzet felvételezésének időszakában (1999. június) a transzekt mentén, a társulások határzónájában sủrübben, a homogén sávokban ritkábban történt. A mintavételre kiválasztott kvadrátok $(1-12,14-16 ; 18 ; 20$; 24 ill. 29) területéről háromszoros ismétlésben, $0-20 \mathrm{~cm}$ mélységböl vettünk mintát

Laboratóriumi vizsgálatok. - A talajminták feldolgozása és analízise a Talajés agrokémiai vizsgálati módszerkönyv (BUZÁs, 1998, 1993) ajánlott módszerei szerint történt.

A talaj nedvességtartalmának meghatározását szárítószekrényes módszerrel végeztük. Az előkészített talaj (légszáraz, 2 mm-es szitán átengedett) pH-értékét elektrometriásan, kombinált üvegelektróddal, szuszpenzióban mértük, a szuszpenzió talaj:folyadék (desztillált víz) aránya 1:2,5 volt. A telítési \%-ot (SP) BUZÁs (1998) szerint állapítottuk meg. A talaj elektromos vezetőképességének meghatározását a telítési talajpépből Radelkis OK-102/1 típusú vezetőképesség mérővel, $0,65 \mathrm{~cm}^{-1}$ cellaállandójú merülőelektróddal végeztük. 


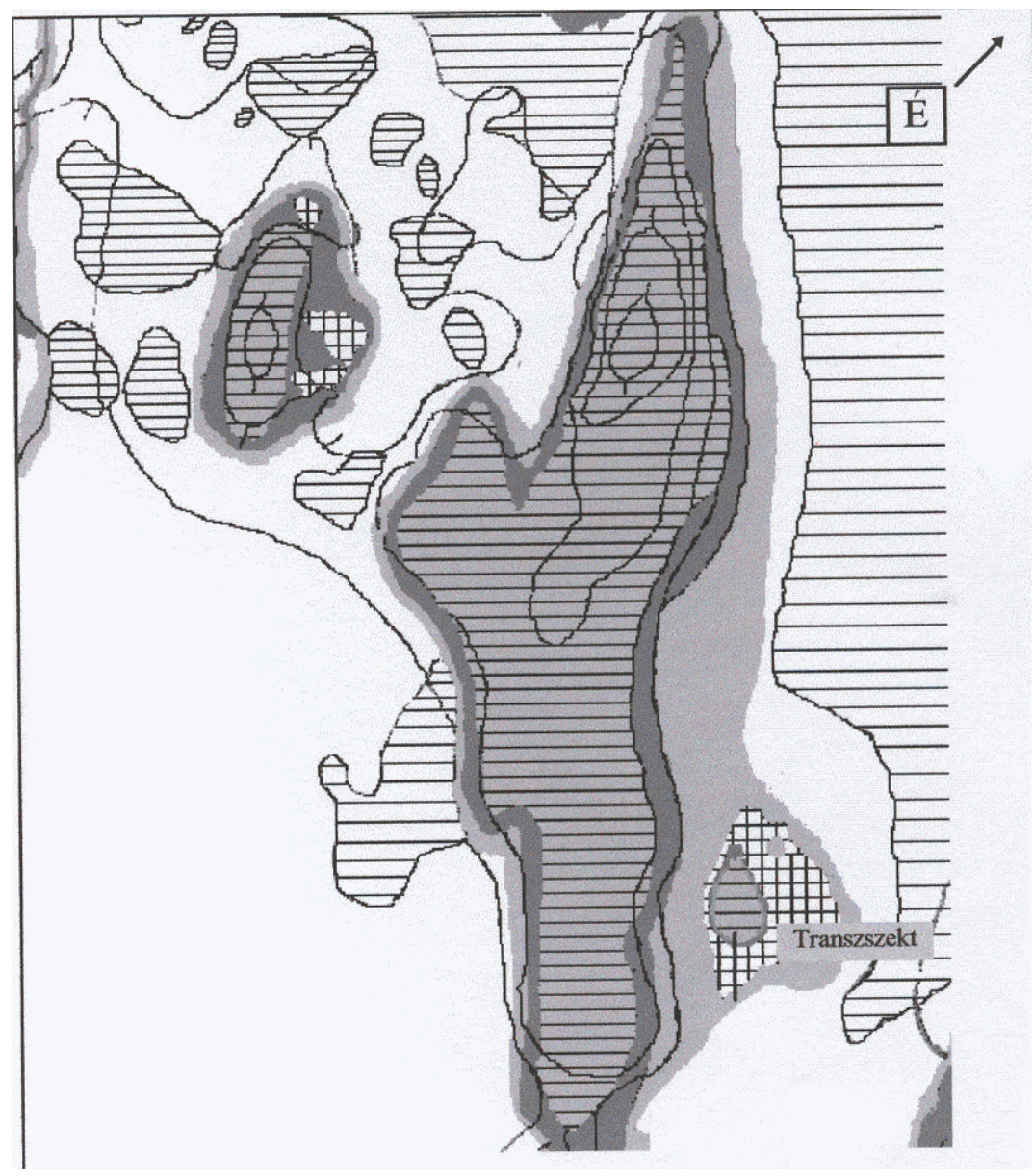

1. ábra

A kutatási terület vegetáció térképe (szintvonalak 0,5 m-enként)

Bolboschoeno-Phragmitetum

Lepidio-Puccinellietum puccinellietosum

册 Lepidio-Puccinellietum lepidietosum
Bolboschoenetum maritimi

Agrostio-Caricetum distantis

Achilleo-Festucetum pseudovinae

A talaj 1:5 arányú desztillált vizes kivonatának kation elemzését ICP-AES készüléken végeztük. Jelen közleményben az eredmények közül csak négy, a szikes talajképződési folyamatokban, valamint a növények sótoleranciájának élettani vizsgálatában leginkább jelentős elem (kálium, nátrium, kalcium, magnézium) szerepét tárgyaljuk. 
Statisztikai módszerek és adatfeldolgozások. - A növényzet és a talaj vizsgált paramétereiben mutatkozó térbeni változatosságot sokváltozós adatfeltárási módszerrel vizsgáltuk. A növényzeti zónák elkülönítéseihez a domináns növényfajok relatív borításértékei alapján végzett cluster analízis eredményeit használtuk fel. A transzekt mentén gyüjtött talajminták analízise során kapott eredményekre (nedvességtartalom, $\mathrm{pH}, \mathrm{SP}$, vezetőképesség, az 1:5 arányú kivonat kation-koncentrációi) szintén elvégeztük a sokváltozós elemzést. Az analízis során az euklideszi és Bray-Curtis-féle távolságfüggvényt alkalmaztuk, az összevonásokhoz a Ward-Orlóci-féle fúziós algoritmust használtuk (TóTHMÉRÉSZ, 1993).

\section{Vizsgálati eredmények és értékelésük}

\section{Vegetáció térkép}

A növénytársulások térbeni elrendeződését a kb. 5 ha-os területről készített vegetáció térképen követhetjük figyelemmel, ahol 5 növénytársulás különböztethető meg (1. ábra). A legmélyebben fekvő, állandó vízborítás alatt álló területeken kiterjedt nád (Phragmites australis ((Cav.) Trin. ex Steudel)) által dominált foltok találhatók. A nádas foltok közötti vízállásos részeken a félsós vizeket kedvelő Bolboschoenus maritimus ((L.) Palla) és a Schoenoplectus tabernaemontani ((C. C. Gmel) Palla) kiterjedt, keveredő állományokat (Bolboschoenetum maritimi (Eggler, 1933) alkot. E három növényfajt a szikinádas (Bolboschoeno-Phragmitetum Borhidi et Balogh 1970) társulás tagjaiként írják le. A változó vízállású részek alacsonyabban fekvő zónájában a Puccinellia limosa ((Schur) Holmgb.) (Lepidio-Puccinellietum limosae puccinellietosum (Topa 39)) alkot kiterjedt, többnyire homogén állományokat, a kiszáradó felszínű részeken a Lepidium crassifolium (W. et K.) borítása a meghatározó (Lepidio-Puccinellietum limosae lepidietosum (Bodrogközy 58.c)). Az ennél magasabb térszínen, melyet a változó vízborítás már nem, vagy csak kevésbé érint az Agrostio-Caricetum distantis /Rapaics ex Soó 1938) társulás figyelhető meg. A hátak tetejének növényzetét különbözö növénytársulások komplexei alkotják. Az eredeti növényzetet az Achilleo-Festucetum pseudovinae (Soó (1933) 1947 corr. Borhidi 1996) társulás képviselheti, állományai azonban meglehetősen degradáltak, zavarástürő fajokkal (pl. Cynodon dactylon ((L.) Pers.), Bromus mollis (L.)) dúsultak (BAGI, 1999a,b; SoÓ, 1964; VARGA \& VARGÁNÉ, 1999a,b,c,d). A hátak növénytársulásainak szubasszociációi és faciesei az 1:5000 méretaránynál nem tüntethetőek fel.

\section{Transzekt menti vizsgálatok}

A mikrodomborzat szerepe a növényzet elrendezödésében. - A növénytársulások elrendeződésében mutatkozó törvényszerüségeket a térképezett terület 
$\mathrm{K}$-i részén, a homokhátról lefutó $30 \mathrm{~m}$-es transzekt mentén (1. ábra) pontosítottuk.

A transzekt menti növényzet összetételében mutatkozó változások egyértelmüen végigkövethetőek, ha a transzekt menti kvadrátok legnagyobb \%-os relatív borítással rendelkezö növényfajainak (Festuca pseudovina (Hack. Ex Wiesb.), Carex distans (L.), Lepidium crassifolium (W. et K.), Puccinellia limosa ((Schur) Holmgb.)) borításgörbéit vizsgáljuk (2. ábra). A növényzet

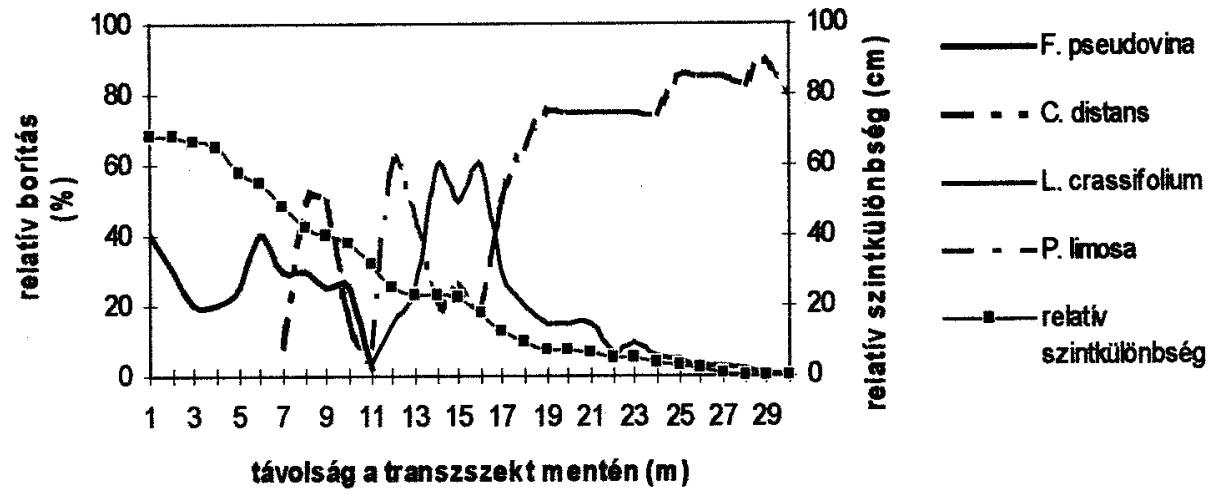

2. ábra

A domináns növényfajok borításértékeinek és a felszín relatív szintkülönbségének változása a transzekt mentén

összetételében megfigyelhető változások szoros összefüggést mutatnak a transzekt relatív szintkülönbségének csökkenésével. A legnagyobb szintcsökkenés a transzekt 10-12. m közötti szakaszán következik be, ahol egyben két növénytársulás, az Agrostio-Caricetum distantis és a Lepidio-Puccinellietum limosae határzónája található.

A $30 \mathrm{~m}$ hosszú transzekt mentén megfigyelhető közel $1 \mathrm{~m}$-es szintcsökkenés jelentős változást jelent a talaj sóforgalmi viszonyaiban. A talajvízszint közelsége miatt a sófelhalmozódási folyamatok fokozottabban érvényesülhetnek, melyek a transzekt középső részén sótürő (pl. C. distans), míg az alsó, legmélyebben fekvő részén sókedvelő növények (L. crassifolium, P. limosa) tömeges megjelenésében tükröződnek.

A cluster analízis eredményei. - A növényzet térbeli elrendeződése és a talajjellemzők változatossága közötti összefüggések elemzéséhez elvégeztük a transzekt növényzetének és a talajminták adatsorainak cluster analíziseit. A növényzet analízise során kapott dendrogram (3. ábra) alapján a transzektet négy egymást követő zónára különíthetjük el $\left(\mathrm{C}_{\mathrm{N}}, \mathrm{D}_{\mathrm{N}}, \mathrm{E}_{\mathrm{N}}, \mathrm{F}_{\mathrm{N}}\right)$. Ez a négy zóna két fö 


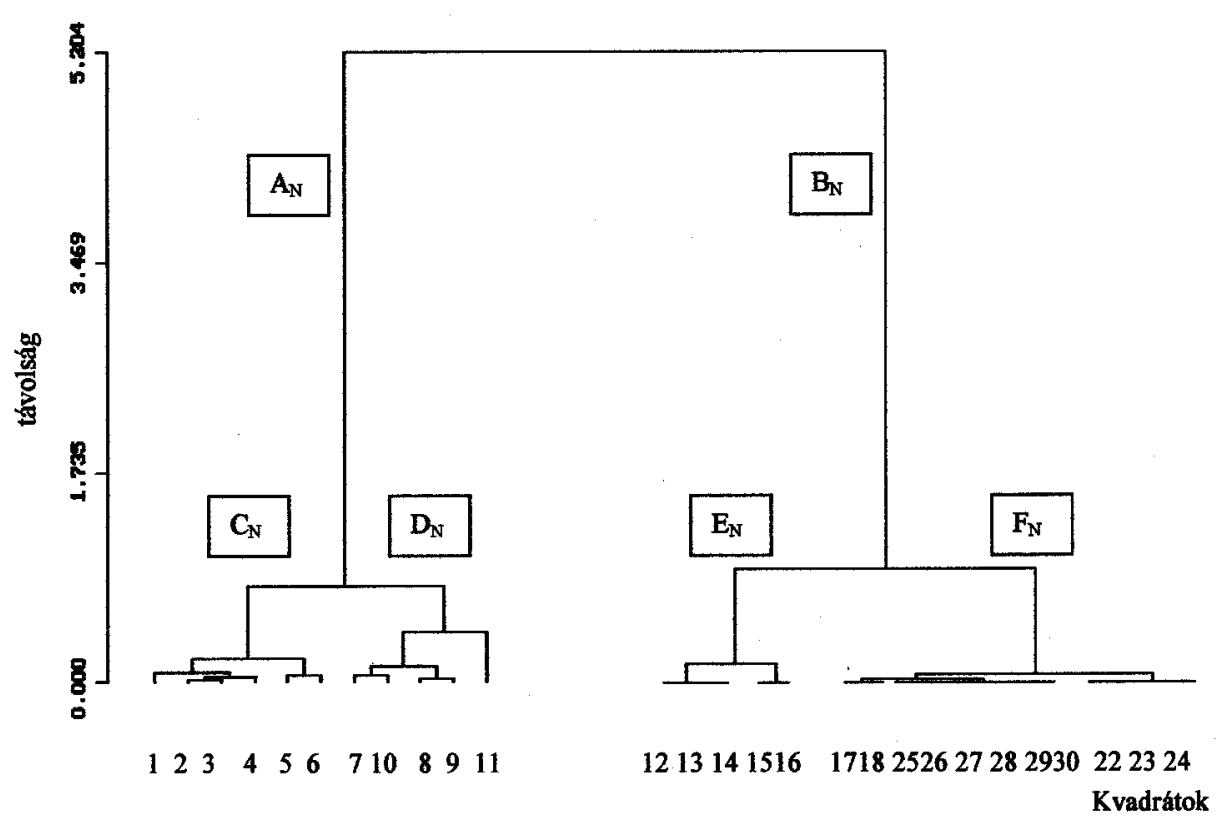

3. ábra

A növényfajok borításértékei alapján cluster analízissel kapott dendrogram kvadrátcsoportosulásai (Bray-Curtis-féle távolságfüggvény, Ward-Orlóci-féle fúziós algoritmus)

szakaszra oszlik $\left(\mathrm{A}_{\mathrm{N}}, \mathrm{B}_{\mathrm{N}}\right)$. A felső, fajgazdag kvadrátok csoportjai $\left(\mathrm{C}_{\mathrm{N}}\right.$ : 1-6 m, ill. $D_{\mathrm{N}}: 7-11 \mathrm{~m}$ ) élesen elhatárolódnak a transzekt távolabbi részeinek két-három faj által dominált kvadrátjaitól $\left(\mathrm{E}_{\mathrm{N}}: 12-16 \mathrm{~m}\right.$, ill. $\left.\mathrm{F}_{\mathrm{N}}: 17-30 \mathrm{~m}\right)$. A dendrogram kvadrátcsoportosulásai és a borításgörbék alapján elkülönülő transzektszakaszok határai pontosan megegyeznek.

A talajelemzésekhez kiválasztott kvadrátok a vizsgált paraméterek alapján szintén négy csoportra különültek el $\left(\mathrm{C}_{\mathrm{T}}: 1-6 \mathrm{~m}, \mathrm{D}_{\mathrm{T}}: 7-11 \mathrm{~m}, \mathrm{E}_{\mathrm{T}}: 12-14 \mathrm{~m} ., \mathrm{F}_{\mathrm{T}}\right.$ : 15-29 m), melyek a transzektet a növényzet elemzése során kapott kvadrátcsoportosulásokkal megegyező részen két fő szakaszra bontják $\left(\mathrm{A}_{\mathrm{T}}\right.$ : 1-11., ill. $\mathrm{B}_{\mathrm{T}}$ : 12-29.) (4. ábra).

\section{Talajvizsgálatok}

A vizsgált talajparaméterek (nedvességtartalom, pH, SP, vezetőképesség, elemtartalom) alapján a legtöbb következtetést a mikrodomborzat és a sófelhalmozódási folyamatok közötti összefüggésekre, a sóakkumuláció mértékére vonhatunk le (1. táblázat). 


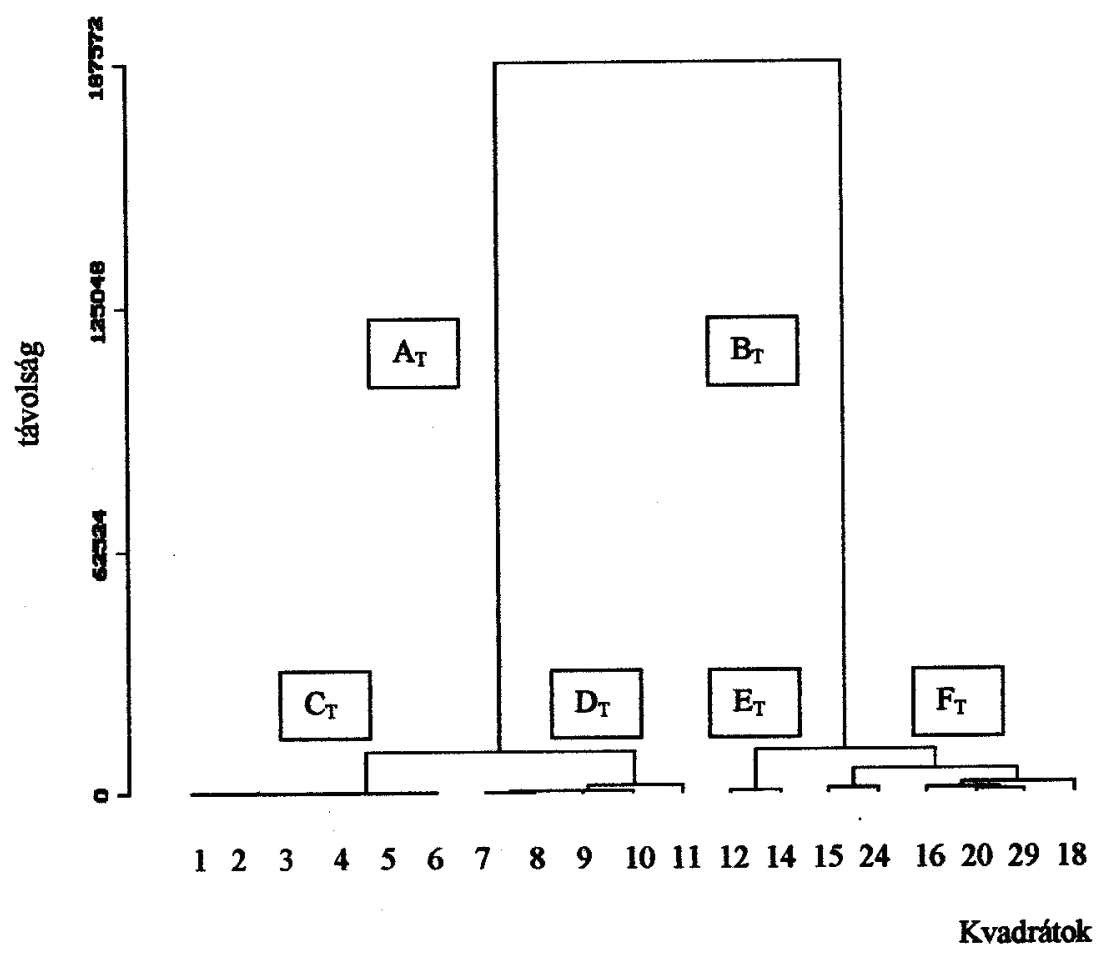

4. ábra

A transzekt menti talajelemzések alapján cluster analízissel kapott dendrogram kvadrátcsoportosulásai (euklidészi-távolságfüggvény, Ward-Orlóci-féle fúziós algoritmus)

\section{1. táblázat}

A talajvizsgálatok eredményei (a kvadrátok mintáinak átlaga ( \pm szórás, $n=9-12$ )

\begin{tabular}{|l|c|c|c|c|}
\hline \multirow{2}{*}{$\begin{array}{c}\text { Talaj- } \\
\text { paraméterek }\end{array}$} & \multicolumn{4}{|c|}{ Kvadrátcsoportosulások* (lásd 4. ábra) } \\
\cline { 2 - 5 } $\mathbf{C}_{\mathbf{T}}$ & $\mathbf{D}_{\mathbf{T}}$ & $\mathbf{E}_{\mathbf{T}}$ & $\mathbf{F}_{\mathbf{T}}$ \\
\hline $\begin{array}{c}\text { Aktuális nedves- } \\
\text { ségtartalom, \% }\end{array}$ & $20,57( \pm 0,85)$ & $22,81( \pm 0,97)$ & $17,64( \pm 0,22)$ & $22,38( \pm 1,09)$ \\
$\begin{array}{l}\mathrm{SP}\left(\mathrm{cm}^{3} / 100 \mathrm{~g}\right. \\
\text { talaj) }\end{array}$ & $36,69( \pm 0,46)$ & $41,41( \pm 0,86)$ & $27,62( \pm 0,50)$ & $27,66( \pm 0,45)$ \\
$\begin{array}{l}\text { Vezetöképesség } \\
(\mathrm{mS} / \mathrm{cm})\end{array}$ & $1,15( \pm 0,04)$ & $1,43( \pm 0,12)$ & $5,35( \pm 0,20)$ & $3,23( \pm 0,10)$ \\
$\mathrm{pH}\left(\mathrm{H}_{2} \mathrm{O}\right)$ & $7,87( \pm 0,12)$ & $8,72( \pm 0,07)$ & $10,21( \pm 0,01)$ & $9,95( \pm 0,03)$ \\
$1: 5$ arányú kivonat kation-koncentrációja & & \\
$\mathrm{Na}^{+}$ & $6,49( \pm 1,02)$ & $55,16( \pm 6,14)$ & $320,09( \pm 35,1)$ & $199,95( \pm 11,8)$ \\
$\mathrm{K}^{+}$ & $9,28( \pm 0,91)$ & $18,74( \pm 1,32)$ & $23,76( \pm 3,51)$ & $15,24( \pm 0,82)$ \\
$\mathrm{Ca}^{2+}$ & $27,10( \pm 3,12)$ & $19,55( \pm 2,50)$ & $45,63( \pm 3,36)$ & $40,36( \pm 4,38)$ \\
$\mathrm{Mg}^{2+}$ & $9,83( \pm 1,19)$ & $21,17( \pm 2,22)$ & $92,89( \pm 7,05)$ & $64,15( \pm 6,60)$ \\
\hline
\end{tabular}


A vizsgálati területen kijelölt transzekt mentén a növényzet összetétele és a talajvizsgálatok sokváltozós analízise eredményeképpen elkülönülő transzektcsoportoknak (C, D, E ill. F) megfelelő transzektszakaszok (C:1-6 m-ig, D: 711 m-ig, E: 12-14 m-ig, F: 15-30 m-ig) a sóakkumulációs folyamatokban eltérő mértékben érintettek.

Azok a területek, melyek sosem kerülnek vízborítás alá (C- és D-szakasz) a talajvíztől való távolságuk miatt a sóakkumulációs folyamatokban egyáltalán nem (C-szakasz: alacsony $\mathrm{Na}^{+}$-koncentráció, enyhén lúgos $\mathrm{pH}$-értékek), vagy csak kismértékben (D-szakasz) érintettek. A D-szakaszon a talaj felső rétegének aktuális nedvességtartalma, valamint a telítési \% növekszik, az előző zónától jobb víztartó képességet mutat. A vízoldható elemkoncentrációk nagyságrendileg meghaladják a felső (C-) szakaszon mért értékeket. A talaj pH-ja a 8,8 körüli értékkel már a lúgosan hidrolizáló sók enyhe felszíni felhalmozódására utal.

A transzekt legnagyobb (mintegy $20 \mathrm{~cm}$-es) szintesése utáni, ellaposodó, enyhe lejtésű szakaszán (E) a felszíni víz időjárástól függő intenzitású evaporációja a pangó, sós talajvíz felszín felé áramlásával a vízoldható sók felszíni, felszín közeli akkumulációjához vezet. A talaj aktuális nedvességtartalma, valamint az SP értéke 30-35\%-kal csökken. A kiszáradó talajfelszínen a sófelhalmozódást a vezetőképesség és a $\mathrm{pH}$ növekedése, valamint az 1:5 arányú kivonatból vizsgált négy kation - de különösen a $\mathrm{Na}^{+}$ill. $\mathrm{Mg}^{2+}$ - értékeiben bekövetkezett nagyságrendi ugrás jelzi. Ezen a transzektszakaszon a talaj legfelső rétegének magas sótartalmából adódóan gyakori a sókivirágzás.

A negyedik, egyben legmélyebben fekvő zónában $\left(\mathrm{F}_{\mathrm{T}}\right)$ a huzamosabb ideig tartó vízborítás miatt a vízoldható sók felhalmozódása akadályozott, a kationkoncentrációk az előző, már kiszáradt felszínü termőhelyhez képest alacsonyabbak. A vízborítás sófelhalmozódást gátló hatása az E-szakaszéhoz képest alacsonyabb pH-értékekben is megnyilvánul.

\section{Összefoglalás}

A Duna-Tisza közi hátságra és annak K-i peremére jellemző geomorfológiai megjelenés az alapkőzet különbözősége miatt számottevő eltérést mutat a tiszavölgyi, illetve tiszántúli területek elszikesedett mélyedéseinek geomorfológiai és botanikai viszonyaitól, mely a talajtani jellemzőkben és ezzel összefüggésben a növényzet összetételének zonális változásában is nyomon követhetö.

A relatív szintkülönbségnek a talajjellemzők alakulásában és a növényzet elrendeződésében megmutatkozó elsődleges szerepe a talajfelszín talajvízszinttől való távolságának változásával és ennek a tényezőnek a szikesedési folyamatokban való jelentős szerepével magyarázható.

A transzekt menti vizsgálatok során a legnagyobb \%-os relatív borítással rendelkező növényfajok borításgörbéi a transzekt menti növényzet borításértékei alapján végzett cluster analízis eredményeivel szoros összefüggést mu- 
tattak. A növényzeti zónák jól elhatárolódnak, a növényzet összetétele pedig a szintkülönbség csökkenésével és a sóakkumulációs folyamatok hatásának növekedésével a sótürő, majd egyre inkább a sókedvelő fajok dominánssá válásával jellemezhető. A sóakkumulációs folyamatokban kizárólag az alacsonyabb térszínek, ezek közül pedig leginkább a periodikusan változó vízborítással és pangó talajvízzel rendelkező, kiszáradó talajfelszínủ zóna érintett. Ez a zóna sókivirágzásos vakszikfoltjaival és a szélsőséges abiotikus tényezőkhöz való alkalmazkodás révén összetett adaptációs mechanizmussal rendelkező, a DunaTisza közén jellegzetes halofiton vakszik és szikfok növényzettel (LepidioPuccinellietum limosae lepidietosum et puccinellietosum szubassz.) jellemezhetö.

A térképezés során alkalmazott módszer eredményei (a vegetáció térkép zonációsorai) a borításgörbék alkalmazásával, valamint a transzekt mentén elöforduló összes növényfaj borításértékének és a talajminták adatsorainak sokváltozós analízisével, azaz egyre objektívebb elemzési módszerek alkalmazásával tesztelhetővé váltak. A légi fotó foltjai és a terep referenciaadatai alapján tervezett talajmintavételezési módszer (a társulások határzónájában sürübben, a homogén sávokban ritkábban végzett mintavételezés), a növényzet térbeli elrendeződése és a vizsgált talajtulajdonságok közötti összefüggés elemzéséhez elégségesnek bizonyult.

\section{Irodalom}

BAGI, I., 1986. The vegetation map of the Kisapaj UNESCO Biosphere Reserve Core Area, Kiskunság National Park, Hungary. Acta Biol. Szeged. 33. 63-74.

BAGI, I., 1988. The vegetation map of the Szívós-szék UNESCO Biosphere Reserve Core Area, Kiskunság National Park, Hungary. Acta Biol. Szeged. 34. 83-95.

BAGI, I., 1990. The vegetation map of the Szappan-szék UNESCO Biosphere Reserve Core Area, Kiskunság National Park, Hungary. Acta Biol. Szeged. 36. $27-42$.

BAGI I., 1999. 7.2.1.4. Sziki kákás. In.: Vörös könyv Magyarország növénytársulásairól I. (Szerk.: BORHIDI A. \& SÁNTA A.) 167-168. TermészetBÚVÁR Alapítvány Kiadó. Budapest

BAGI I., 1999. 7.2.1.5. Sziki nádas. In.: Vörös könyv Magyarország növénytársulásairól I. (Szerk.: BORHIDI A. \& SÁNTA A.) 168-169. TermészetBÚVÁR Alapítvány Kiadó. Budapest

BARNA I-NÉ, 1982. A talaj vízgazdálkodása és a természetes vegetáció közötti kapcsolat egy hidromorf talajsor esetén. Agrokémia és Talajtan. 31. 73-93.

BODROGKÖZY, GY., 1962. Die Standortökologischen Verhältnisse der halophilen Pflanzengesellschaften des Pannonicum. I. Untersuchungen an den SolontschakSzikböden der südlichen Kiskunság. Acta Bot. Ac. Sci. Hung. 8. 1-37.

BODROGKÖZY, GY., 1965a. Ecology of the halophilic vegetation of the Pannonicum. II. Correlation between alkali ("Szik") plant communities and genetic soil classification in the northern Hortobágy. Acta Bot. Ac. Sci. Hung. 11. 1-51. 
BODROGKÖZY, GY., 1965b. Ecology of the halophilic vegetation of the Pannonicum. III. Results of the investigation of the solonetz of Orosháza. Acta Biol. Szeged. 11. $1-25$.

BoDROGKÖZY, GY., 1965c. Ecology of the halophilic vegetation of the Pannonicum. IV. Investigations on the solonetz meadow soils of Orosháza. Acta Biol. Szeged. 11. 207-227.

BodrogkÖZY, GY., 1966. Ecology of the halophilic vegetation of the Pannonicum. V. Results of the investigation of the "Fehértó" of Orosháza. Acta Bot. Acad. Sci. Hung. 12. 9-26.

BODROGKÖZY, GY., 1970a. Ecology of the halophilic vegetation of the Pannonicum. VI. Effect of the soil-ecological factors on the vegetation of the reserve of lake „Dongér” at Pusztaszer. Acta Biol. Szeged. 16. 21-41.

BODROGKÖZY, GY., 1970b. Ecology of the halophilic vegetation of the Pannonicum. VII.. Zonation study along the Bega-backwaters in the Voivodina (Yugoslavia). Acta Biol. Szeged. 16. 25-41.

BUZÁs I. (Szerk.), 1988. Talaj- és agrokémiai vizsgálati módszerkönyv 2. A talajok fizikai-kémiai és kémiai vizsgálati módszerei. Mezőgazdasági Kiadó. Budapest

BuZÁs I. (Szerk.), 1993. Talaj- és agrokémiai vizsgálati módszerkönyv 1. A talaj fizikai, vízgazdálkodási és ásványtani vizsgálata. INDA 4231 Kiadó. Budapest

Kertész, M. \& TóTH, T. 1994. Soil survey based on sampling scheme adjusted to local heterogeneity. Agrokémia és Talajtan. 43. 113-132.

MAGYAR P., 1928. Adatok a Hortobágy növényszociológiai és geobotanikai viszonyaihoz. Erd. Kís. 30. 26-63.

MÁTHÉ I., 1933. A hortobágyi Ohat-erdő vegetációja. Bot. Közl. 30. 163-184.

ProdAn Gy., 1915. Bács-Bodrog vármegye flórája (Flora des Komitates Bács-Bodrog). Magy. Bot. Lapok. 14. 120-269.

RAJKAI K., KERTÉSZ M. \& TÓTH T., 1990. Légifényképezés alkalmazása védett termőhelyek vizsgálatában. In: A G-10 jelü OKKFT Program keretében végzett kutatások. Környezetgazdálkodási Kutatások 3. (Szerk.: Bocz K.) 62-100. Környezetgazdálkodási Programiroda. Budapest

RajKAi, K., Marchand, D. \& Oertli, J. J., 1998. Study of the spatial variability of soil properties on alkali soils. In: Proc. Int. Symp. on Solonetz Soils. Osijek, Yugoslavia. 150-155.

RAPAICS R., 1927. A szegedi és csongrádi sós és szikes talajok növénytársulásai. Bot. Közl. 24. 12-29.

SoÓ R., 1934. A Hortobágy növénytakarója. (A szikespuszta növényszövetkezeteinek ökológiai és szociológiai jellemzése.) Debreceni Szemle. 8. 56-77.

Soó R., 1964. Magyar flóra és vegetáció rendszertani-növényföldrajzi kézikönyve I. (Synopsis systematico-geobotanica florae vegetationisque Hungariae I.) Akadémiai Kiadó. Budapest

STRÖMPL G., 1931. A szik geomorfológiája. Földr. Közl. 59. 62-74.

SzABOLCS I. \& JASSÓ F., 1959. A magyar szikes talajok osztályozása. Agrokémia és Talajtan. 8. 281-297.

SzABOLCS I. \& JASSÓ F., 1961. A szikes talajok genetikus típusai és elterjedésük törvényszerüségei a Duna-Tisza közén. Agrokémia és Talajtan. 10. 173-194.

SzABOlCS I. \& MOLNÁR E., 1980. A talajképződés tényezői és talajképződési folyamatok Cegléd környékének szikes területein. Agrokémia és Talajtan. 29. 7-34. 
TÓTH, T. \& Kertész, M., 1993. Mapping the degradation of solonetzic grassland. Agrokémia és Talajtan. 42. 43-54.

Tóth T. \& RAJKAI K., 1994. Soil and plant correlations in a solonetzic grassland. Soil Science. 157. 253-262.

TÓTH, T., KerTÉSz, M. \& PÁszTOR, L., 1998. New approaches in salinity/sodicity mapping in Hungary. Agrokémia és Talajtan. 47. 76-87.

То́тн, T. et al.,, 1991. Characterization of semivegetated salt-affected soils by means of field remote sensing. Remote Sens. Environ. 37. 167-180.

TóthMERÉSZ, B., 1993. NuCoSA 1.0. Number Cruncher for Community Studies and other Ecological Applications. Abstract Botanica. 7. 283-287.

TUZSON J., 1915. A magyar Alföld növényföldrajzi tagolódása. Akadémiai Math. és Természettud. Értesítö. 33. 170-176.

UNGÁR T., 1956. A Kistelektől északra levő terület felszíni képződményei. Földrajzi Értesítő. 3. 283-297.

VARGA Z. \& VARGÁNÉ SiPOS JÚLIA, 1999a. 11.1.5b.1. Kiskunsági szikfoknövényzet. In.: Vörös könyv Magyarország növénytársulásairól I. (Szerk.: BoRHIDI A. \& SÁNTA A.) 253-254.. TermészetBÚVÁR Alapítvány Kiadó. Budapest

VARGA Z. \& VARGÁNÉ SIPOS JÚliA, 1999b. 11.1.5b.2. Kiskunsági vaksziknövényzet. In.: Vörös könyv Magyarország növénytársulásairól I. (Szerk.: BORHIDI A. \& SÁNTA A.) 254-255. TermészetBÚVÁR Alapítvány Kiadó. Budapest

VARGA Z. \& VARGÁNÉ SIPOS JÚLIA, 1999c. 11.1.1.2. Sziki sásrét. In.: Vörös könyv Magyarország növénytársulásairól I. (Szerk.: BorHIDI A. \& SÁNTA A.) 232. TermészetBÚVÁR Alapítvány Kiadó, Budapest

VARGA Z. \& VARGÁNÉ Sipos Júlia, 1999d. 11.1.4.1. Füves szikes puszta. In.: Vörös könyv Magyarország növénytársulásairól I. (Szerk.: BORHIDI A. \& SÁNTA A.) 244-246. TermészetBÚVÁR Alapítvány Kiadó, Budapest

VÁrallyay Gy., Molnár E. \& RAJKAi K., 1984. Talajképződési folyamatok a Péteritó környékén. (Kézirat)

Érkezett: 2001. február 21. 